\title{
Assessment of Metal Chelating, Bioautography and Spot Screening by TLC of Green Tea (Camellia sinensis)
}

\author{
Arti Ghabru ${ }^{*}$ and R.G. Sud ${ }^{2}$ \\ ${ }^{1}$ Department of Basic Sciences, College of Forestry, UHF, Nauni, Solan, HP, India \\ ${ }^{2}$ Department of Chemistry and Biochemistry, COBS, CSKHPV, Palampur, HP, India \\ *Corresponding author
}

\section{A B S T R A C T}

\begin{tabular}{|l|}
\hline Ke y w o r d s \\
Green tea, Metal \\
Chelating ions, \\
Antibacterial assay, \\
Antioxidant \\
activity, \\
Phytochemical \\
screening, \\
Camellia sinensis. \\
\hline Article Info \\
\hline $\begin{array}{l}\text { Accepted: } \\
\text { 04 September } 2017 \\
\text { Available Online: } \\
\text { 10 October } 2017\end{array}$ \\
\hline
\end{tabular}

\section{Keywords}

Green tea, Metal Chelating ions, Antibacterial assay, activity, Phytochemical screening, Camellia sinensis.

\section{Introduction}

For more than 1000 years green tea has been used in China and Japan as a medical herb and a healthful beverage. The traditional Chinese medicine has recommended this plant for headaches, body aches and pains, digestion, depression, detoxification, as an energizer and, in general, to prolong life. Tea is made from young shoots and leaves of the plant Camellia sinensis (Willson and Clifford 1992; Cabrera et al., 2006; Sharma et al., 2007).

Reasons for the vast use of medicinal plants are high cost of allopathic drugs and their side effects (Marwat et al., 2008). Majority of the human beings died mostly due to infectious bacterial diseases in the developing countries (Nathan 2004). The synthetic antibiotics that are being used also became ineffective because the pathogens got resistance against these antibiotics (Walsh and Amyes, 2004).

Various strategies have been developed during the past decade e.g., biological screening, isolation as well as clinical trials for a variety of plants to explore the secret of their therapeutic actions. Now a day, bioactive plant extracts are considered as a 
promising source of biological friendly antibacterial agents (Koehan and Carter 2005).

Fresh tea leaves contain caffeine, tea polyphenols, tea polysaccharides, and necessary nutrients, such as protein, amino acids, lipids, and vitamins. Generally, four chemical components - free amino acids, total tea polyphenols, soluble sugars, and caffeine - are considered indicators of tea quality (Yamamoto et al., 1997; Bashir et al., 2014; Gogoi and Barua 2017). It is of the interest to note that the polyphenols found in fresh green tea shoots are different from other polyphenols of plant origin as most of them are found only in leaves of tea plant. Tea catechins have been used as antioxidant compounds in many food matrices such as meats, poultries, fishes and vegetable oils (Yilmaz 2006). Since tea has an antimicrobial activity against a large spectrum of pathogenic bacteria (Chou et al., 1999, Gramza et al., 2005; Friedman et al., 2006; Freidman 2007). Its low $\mathrm{pH}$ value, of approximately 4.2 , makes tea compatible with many food products in term of acidity.

Epidemiological studies during the recent years have suggested that green tea reduces risks of several chronic diseases including cancer and cardiovascular disorders by increasing plasma antioxidant capacity in humans (Nakagawa et al., 1999; Duthie et al., 2000). In the present study, we have investigated the bioactivity of green tea, cultivated at Wah tea estate, Rajpura, HP.

\section{Materials and Methods}

\section{Preparation of tea powders}

Tea powders were prepared by lyophilizing aqueous extracts of dried green tea with the help of Edwards $\mathrm{EF}_{4}$ Modulyo freeze dryer and Heto Power Dry LL 3000 freeze dryer. The powders so obtained were immediately transferred into glass tubes fitted with airtight stoppers which were stored in vacuum desiccator.

\section{Estimation of total catechins}

Total catechins were always estimated in freshly prepared tea extracts by the method of Sun et al., (1998).

\section{Thin- layer chromatography}

Thin layer chromatography was done on glass plate coated with silica gel $\mathrm{G}$ by the method of Stahl (1969). Standard solutions were prepared $\left(0.5 \mathrm{mg} \mathrm{mL}^{-1}\right)$. (+)-catechin, (-)epicatechin, (-)-epigallocatechin gallate, $(-)$ epicatechin gallate and (-)-epigallocatechin were procured from (Sigma, USA). Solvent system was used: Chloroform: Ethyl acetate: Acetic Acid:: 25:75:0.5 (By volume)

\section{Metal ions chelation assay}

The binding potency of metal ions by tea catechins was evaluated using method of Tang et al., (2002). The technique for the evaluation of metal ions chelation by the tea catechins a method was standardized using standard chelating agents namely EDTA (1 $\mathrm{mM})$ and citric acid $(25 \mathrm{mM})$. The value of slope and y-intercept were evaluated from a plot (Figures 1) between \% chelating activity and concentration of EDTA and Citric Acid.

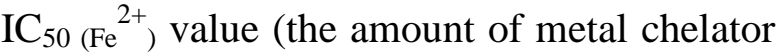
necessary to decrease the initial ferrous ions concentration by 50\%) for EDTA was evaluated using the following equation:

$\mathrm{IC}_{50\left(\mathrm{Fe}^{2+}\right)}$ Value $=(50-\mathrm{y}$-intercept $) /$ slope

\section{Evaluation of tea samples}

The metal ions chelation activity of tea catechins was evaluated in aqueous solutions of tea powders by following protocol: 
The sample solution have pale yellow color and sample volumes used for evaluating metal ions chelating activity were quite large, it was noted that sample form blue color with ferrous ions.

To correct this occurrence, sample blanks containing the appropriate dilution of each volume of sample with $2 \mathrm{mM} \mathrm{FeCl} 2 \cdot 7 \mathrm{H}_{2} \mathrm{O}$ solution $(0.1 \mathrm{~mL})$ were used. The absorbance of each sample blank was subtracted from the absorbance of sample, respectively. The final absorbance so obtained was used for further calculations.

\section{Antibacterial activity}

Growth inhibitory activity of tea powder of fresh green tea shoots was evaluated against selected pathogenic bacteria i.e. Bacillus cereus (MTCC-1272) and Staphylococcus aureus (MTCC-96) procured from the Institute of Microbial Technology (IMTECH), Chandigarh.

The bacterial cultures were maintained on freshly prepared nutrient agar (NA) medium and were stored at $4 \pm 0.5^{\circ} \mathrm{C}$ for further use.

\section{Agar-well diffusion method for antibacterial activity}

Antibacterial activities of tea powder prepared from green tea shoots were evaluated by the method of Toda et al., (1989a). The antibacterial activity was always determined in freshly prepared extracts/solutions.

\section{Bioautography}

A TLC bioautographic method as described by Kline and Golab (1965) was used to detect active antibacterial components present in tea powder. For this $50 \mu \mathrm{L}$ of aqueous solution of tea powder $\left(1 \mathrm{mg} \mathrm{mL}^{-1}\right)$ was applied on silica gel G TLC plate which was developed by using chloroform: ethyl acetate: acetic acid (25:75:0.5) as the solvent system and then dried for complete removal of solvent. Then TLC plate was placed in the Petri dish and 0.1 $\mathrm{mL}$ of inoculum of Bacillus cereus (MTCC1272) grown in nutrient broth was added to agar medium and this medium was distributed over the entire TLC plate.

The plate was incubated at $37^{\circ} \mathrm{C}$ for $24 \mathrm{~h}$ and the inhibition zone was visualized with $0.1 \%$ of triphenyl tetrazolium chloride solution. Inhibition zone was observed as clear area against a red colored background.

Influence of metal ions on inhibitory properties of aqueous solution of tea powder

Influence of metal ions on inhibitory properties of aqueous solution of tea powder was evaluated using agar-well diffusion method as described by West et al., (2001). The growth inhibition of aqueous solution of tea powder was determined against $B$. cereus and $S$. aureus using agar-well diffusion method as described above. Zones of inhibition were observed, then $0.1 \mathrm{~mL}$ of ferrous sulphate solution was added to one well whereas sterilized double distilled water was added to other well as a control. Plate was kept at $4^{\circ} \mathrm{C}$ for $1 \mathrm{~h}$ to allow diffusion of the solution into the medium. The plate was then incubated at $37^{\circ} \mathrm{C}$ for $24 \mathrm{~h}$ then appearance of growth was observed in inhibition zone.

\section{Results and Discussion}

Mean total catechins (TC) content of fresh green tea shoots varied significantly in the range of 143.242 to $120.930 \mathrm{~g} \mathrm{~kg}^{-1}$. Tea powders obtained by lyophilizing aqueous extracts of green tea shoot samples. The mean TC content in tea powders varied significantly in the range 271.392 to $140.831 \mathrm{~g} \mathrm{~kg}^{-1}$. 


\section{Thin layer chromatography of tea powder}

Thin layer chromatographs (TLC) of standard flavan-3-ols [(+)-catechin (C), (-)-epicatechin (EC), (-)-epigallocatechin (EGC), (-)epigallocatechin gallate (EGCG) and (-)epicatechin gallate (ECG)] and tea powder were presented in Plate I.

\section{Metal ions chelation}

The mean $\left.\mathrm{IC}_{50(\mathrm{Fe}}{ }^{2+}\right)$ values corresponding to chelation of $\mathrm{Fe}^{2+}$ ions by EDTA and citric acid (versatile metal chelators) were estimated to be $1.589 \mu \mathrm{g} \mathrm{mL}^{-1}$ and $1455.895 \mu \mathrm{g} \mathrm{mL}^{-1}$, respectively (Table 1 ).

In table 3 is given the mean monthly $\left.\mathrm{IC}_{50(\mathrm{Fe}}{ }^{2+}\right)$ values (inhibitory concentration necessary to reduce the metal ions concentration by 50 per cent) of aqueous solutions (concentration: 5 $\mathrm{mg} \mathrm{mL}^{-1}$ ) of tea powders obtained by lyophilizing aqueous extracts of samples of fresh green tea shoots along with CD (at 5\%) and per cent $\mathrm{CV}$.

A perusal of table 3 indicates that the mean monthly $\mathrm{IC}_{50}\left(\mathrm{Fe}^{2+}\right)$ values varied significantly in the range: 1243.002 to $724.953 \mu \mathrm{g} \mathrm{mL}^{-1}$ for tea powders. The tea powders obtained by lyophilizing aqueous extracts of fresh green tea shoots harvested during August had lower mean monthly $\mathrm{IC}_{50\left(\mathrm{Fe}^{2+}\right)}$ value. Although these values are comparable with the $\mathrm{IC}_{50}\left(\mathrm{Fe}^{2+}\right)$ value estimated for citric acid but, far higher in comparison to EDTA.

The metal ions chelating potential in terms of $\mathrm{IC}_{50\left(\mathrm{Fe}^{2+}\right)}$ values of tea powders exhibited a significant negative correlation with TC, EGCG, ECG and EGCG+ECG (Table 4).

\section{Antibacterial activity}

In order to evaluate green tea for its biological activity, antibacterial potential of aqueous extracts of samples of fresh green tea shoots were studied against standard bacterial pathogens i.e. Bacillus cereus (MTCC-1272) and Staphylococcus aureus (MTCC-96)

\section{Sensitivity of selected bacterial pathogens for standard catechins}

Before evaluating the tea samples for antibacterial activity, the individual catechins i.e. C, EC, EGC, EGCG and ECG were tested for their antibacterial effect on the selected pathogens (Plate II). Minimum inhibitory concentrations (MIC) of EGC, EGCG and ECG for B. cereus were 375,50 and $250 \mu \mathrm{g}$ $\mathrm{mL}^{-1}$, respectively, whereas for $S$. aureus the MIC of EGC, EGCG and ECG were 500, 250 and $375 \mu \mathrm{g} \mathrm{mL} \mathrm{m}^{-1}$, respectively table 5 indicates that the MIC of aqueous extracts of samples of fresh green tea shoots varies significantly in the range 724.953 to 1243.002 $\mu \mathrm{g} \mathrm{mL}^{-1}$

\section{Bioautography}

In Plate IV the TLC bioautographic result of aqueous solution of tea powder against $B$. cereus is given. The component that corresponded to the zone of inhibition against a red background was at the bottom of the TLC plate where the tea solution was spotted

\section{Influence of metal ions on inhibition properties of tea catechins}

Growth inhibition of the aqueous solution of tea powders on B. cereus and $S$. aureus was influenced by the addition of ferrous ions (Plate V).

Health benefits of tea drinking have been attributed to tea catechins. The present investigations: "Assessment of metal chelating, bioautography and spot screening of TLC of green tea (Camellia Sinensis)" were carried out to elucidated biological activity of green tea. 
Table.1 Protocol of metal ions chelating activity

\begin{tabular}{lllll}
\hline Tube no. & $\begin{array}{l}\text { Vol. of stock } \\
\text { sample solution } \\
(\mathrm{mL})\end{array}$ & $\begin{array}{l}\text { Vol. of double } \\
\text { distilled water } \\
(\mathrm{mL})\end{array}$ & $\begin{array}{l}\text { Vol. of } \mathrm{FeCl}_{2} \\
(\mathrm{~mL})\end{array}$ & $\begin{array}{l}\text { Vol. of } \\
\text { ferrozine }(\mathrm{mL})\end{array}$ \\
\hline $\mathrm{T}_{1}$ (Control) & 0.000 & 2.700 & 0.100 & 0.200 \\
$\mathrm{~T}_{2}$ & 0.240 & 2.460 & 0.100 & 0.200 \\
$\mathrm{~T}_{3}$ & 0.360 & 2.340 & 0.100 & 0.200 \\
$\mathrm{~T}_{4}$ & 0.480 & 2.220 & 0.100 & 0.200 \\
$\mathrm{~T}_{5}$ & 0.600 & 2.100 & 0.100 & 0.200 \\
$\mathrm{~T}_{6}$ & 0.720 & 1.980 & 0.100 & 0.200 \\
$\mathrm{~T}_{7}$ & 0.840 & 1.860 & 0.100 & 0.200 \\
\hline
\end{tabular}

Table. 2 Mean total catechins $\left(\mathrm{g} \mathrm{kg}^{-1}\right)$ contents in tea powders prepared from Fresh green tea shoots

\begin{tabular}{|c|c|c|}
\hline Months & Fresh green shoots & Total catechins \\
\hline April & $120.930^{e}$ & $140.831^{f}$ \\
\hline May & $137.730^{b}$ & $197.627^{d}$ \\
\hline June & $136.242^{b}$ & $226.024^{c}$ \\
\hline July & $132.429^{c}$ & $249.689^{b}$ \\
\hline August & $\mathbf{1 4 2 . 6 4 4}^{a}$ & $\mathbf{2 7 1 . 3 9 2 ^ { a }}$ \\
\hline September & $135.609^{b}$ & $251.041^{b}$ \\
\hline October & $127.097^{d}$ & $185.190^{e}$ \\
\hline Mean & $\mathbf{1 3 2 . 9 5 4}$ & $\mathbf{2 1 7 . 3 9 9}$ \\
\hline CD (5\%) & $\mathbf{4 . 8 6}$ & $\mathbf{1 0 . 7 5}$ \\
\hline CV $(\%)$ & $\mathbf{2}$ & $\mathbf{2 . 8 2}$ \\
\hline
\end{tabular}

Rankings - means within each column followed by the same letter are not significantly different at $p<0.05$.

Table.3 Mean $\mathrm{IC}_{50\left(\mathrm{Fe}^{2+}\right)}$ values $\left(\mu \mathrm{g} \mathrm{mL}^{-1}\right)$ of tea powders from fresh green tea shoots (FGTS)

\begin{tabular}{|c|c|}
\hline Months & FGTS \\
\hline \multicolumn{2}{|c|}{ Mean $\mathrm{IC}_{50\left(\mathrm{Fe}^{2+}\right) \text { values }}$} \\
\hline April & $1243.002^{a}$ \\
\hline May & $1160.127^{b}$ \\
\hline June & $884.435^{d}$ \\
\hline July & $971.934^{c}$ \\
\hline August & $\mathbf{7 2 4 . 9 5 3}^{\boldsymbol{a}}$ \\
\hline September & $890.731^{d}$ \\
\hline October & $985.467^{c}$ \\
\hline Mean & $\mathbf{9 8 0 . 0 9 3}$ \\
\hline CD(5\%) & $\mathbf{4 7 . 6 6}$ \\
\hline CV (\%) & $\mathbf{2 . 7 8}$ \\
\hline
\end{tabular}

Rankings - means within each column followed by the same letter are not significantly different at $p<0.05$. 
Table.4 Correlation coefficient among TP, TC, C, EC, EGC, EGCG and ECG and mean $\mathrm{IC}_{50}$ $\left(\mathrm{Fe}^{2+}\right.$ ) values of tea powders from fresh green tea shoots (FGTS)

\begin{tabular}{|c|c|}
\hline & FGTS \\
\hline \multicolumn{2}{|c|}{${\text { Mean } \mathrm{IC}_{50\left(\mathrm{Fe}^{2+}\right)}{ }^{2+} \text { values }}$} \\
\hline $\mathrm{TP}$ & $-0.77^{a}$ \\
\hline $\mathrm{TC}$ & $-0.87^{a}$ \\
\hline $\mathrm{C}$ & $\mathrm{NS}$ \\
\hline $\mathrm{EC}$ & $\mathrm{NS}$ \\
\hline $\mathrm{EGC}$ & $\mathrm{NS}$ \\
\hline $\mathrm{EGCG}$ & $-0.92^{a}$ \\
\hline $\mathrm{ECG}$ & $-0.80^{a}$ \\
\hline $\mathrm{EGCG}+\mathrm{ECG}$ & $-0.88^{a}$ \\
\hline $\mathrm{TP}$ & $-0.77^{a}$ \\
\hline $\mathrm{TC}$ & $-0.87^{a}$ \\
\hline
\end{tabular}

${ }^{a}$ - Significant at $p<0.05 ; \mathrm{NS}-$ Not significant.

TP - total polyphenols; TC - total catechins; C - catechin; EC - epicatechin; EGC- epigallocatechin; EGCG epigallocatechin gallate and ECG - epicatechin gallate.

Table.5 Mean minimum inhibitory concentrations $\left(\mathrm{mg} \mathrm{mL}^{-1}\right)$ of aqueous extracts of samples of Fresh green tea shoots against selected bacterial pathogens

\begin{tabular}{|c|c|c|}
\hline & Pathogens & \\
\hline \multirow[t]{2}{*}{ Months } & B. cereus & S. aureus \\
\hline & \multicolumn{2}{|c|}{ Mean minimum inhibitory concentrations* } \\
\hline April & $1.541^{f}$ & $2.042^{b}$ \\
\hline May & $1.595^{e}$ & $1.595^{e}$ \\
\hline June & $1.770^{c}$ & $1.770^{c}$ \\
\hline July & $2.025^{b}$ & $2.025^{b}$ \\
\hline August & $1.073^{g}$ & $1.541^{f}$ \\
\hline September & $1.723^{d}$ & $1.723^{d}$ \\
\hline October & $2.253^{a}$ & $2.253^{a}$ \\
\hline Mean & 1.712 & 1.850 \\
\hline CD (5\%) & 0.036 & 0.036 \\
\hline CV (\%) & 1.20 & 1.20 \\
\hline
\end{tabular}

Rankings - means within each column followed by the same letter are not significantly different at $p<0.05$; NZ No inhibition zone detected.

*The minimum inhibitory concentrations are based on total catechins content $\left(\mathrm{mg} \mathrm{mL}^{-1}\right)$ of aqueous extracts. 
Fig.1 A- Graph between EDTA and per cent chelating activity; B- Graph between citric acid and per cent chelating activity

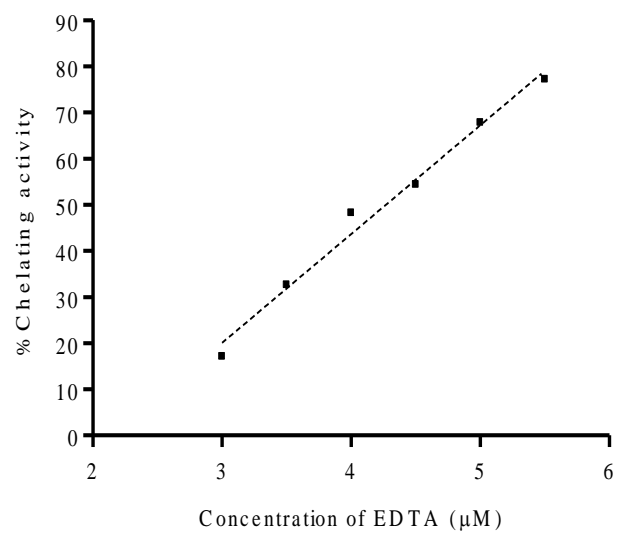

A

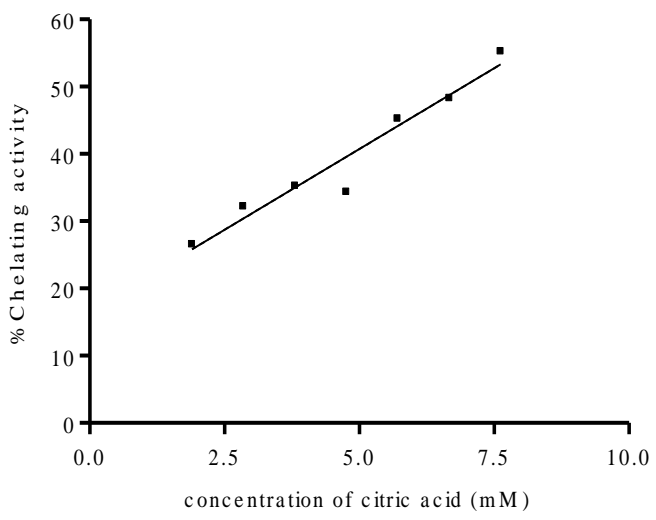

B

A -Slope $=23.56 ; \mathrm{y}$-intercept $=(-) 50.62 ; \mathrm{r}^{2}=0.9857 ; \mathrm{B}-$ Slope $=0.02290 ; \mathrm{y}$-intercept $=16.66 ; \mathrm{r}^{2}=0.9424$

Plate.1 Thin layer chromatogram of tea powders containing significant amounts of flavanols along with standard catechins mixture Solvent system: Chloroform: Ethyl Acetate: Acetic Acid:: 75:25:0.5

$\begin{array}{llllllllllll}\text { Std Mix } & 18 & 19 & 20 & 21 & 22 & 23 & 24 & 25 & 26 & 27 & 28\end{array}$

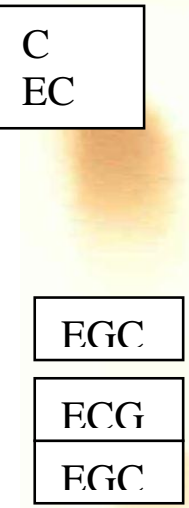


Plate.2 Sensitivity of B. cereus and $S$. aureus against standard catechin and its derivatives

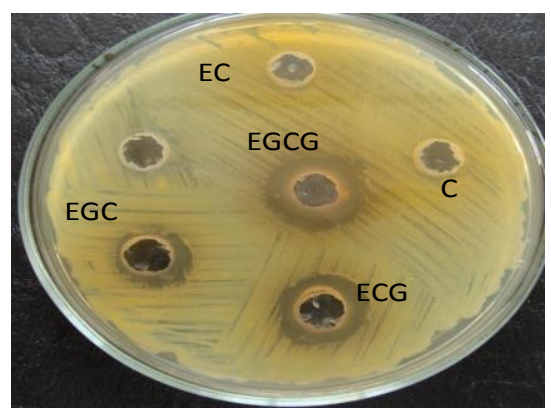

Staphylococcus aureus (MTCC-96)

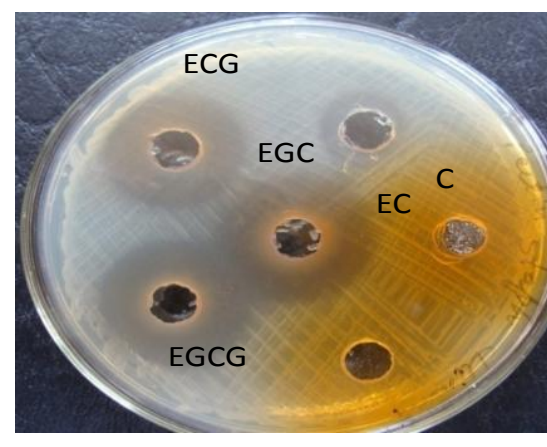

Bacillus cereus (MTCC-1272) L

Plate.3 Sensitivity of B. cereus and S. aureus for aqueous extracts of fresh green tea shoots

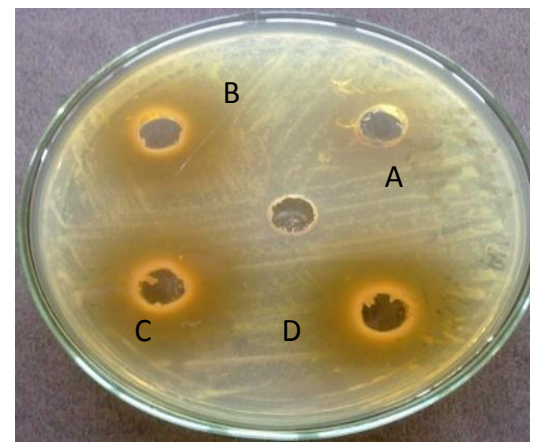

Staphylococcus aureus (MTCC-96)

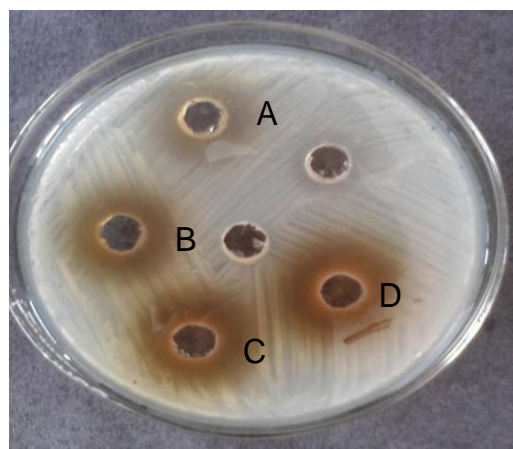

Bacillus cereus (MTCC-1272) L

Plate.4 TLC bioautography of aqueous solution of tea powder of green tea shoots against $B$. cereus along with TLC of tea solution and standard catechins. Solvent system: Chloroform: Ethyl Acetate: Acetic Acid:: 75:25:0.5

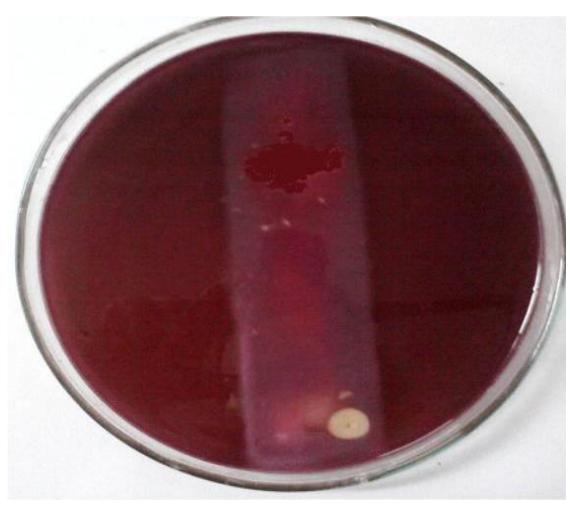

TLC bioautograph of tea solution TLC of tea solution

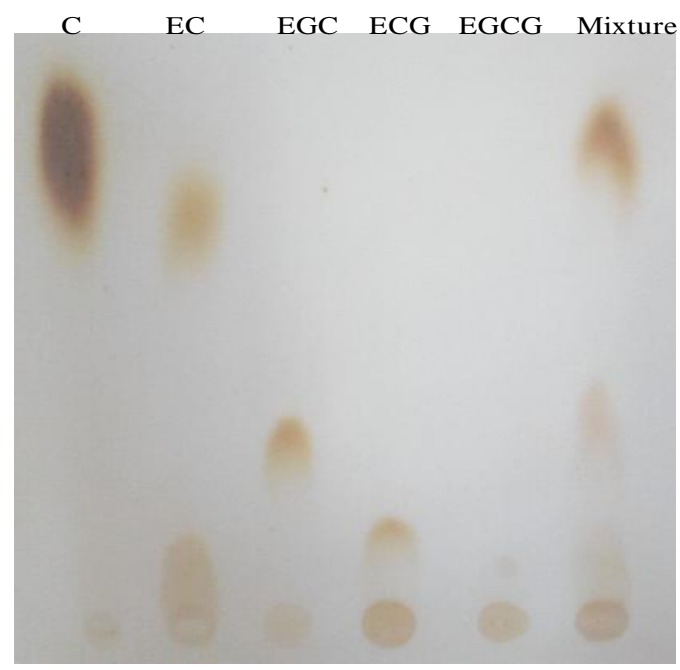

TLC of standard catechins 
Plate.5 Growth inhibition of B. cereus and $S$. aureus by aqueous solution of tea powder (a) in the absence, and (b) showing restoration of growth in the presence of ferrous ions
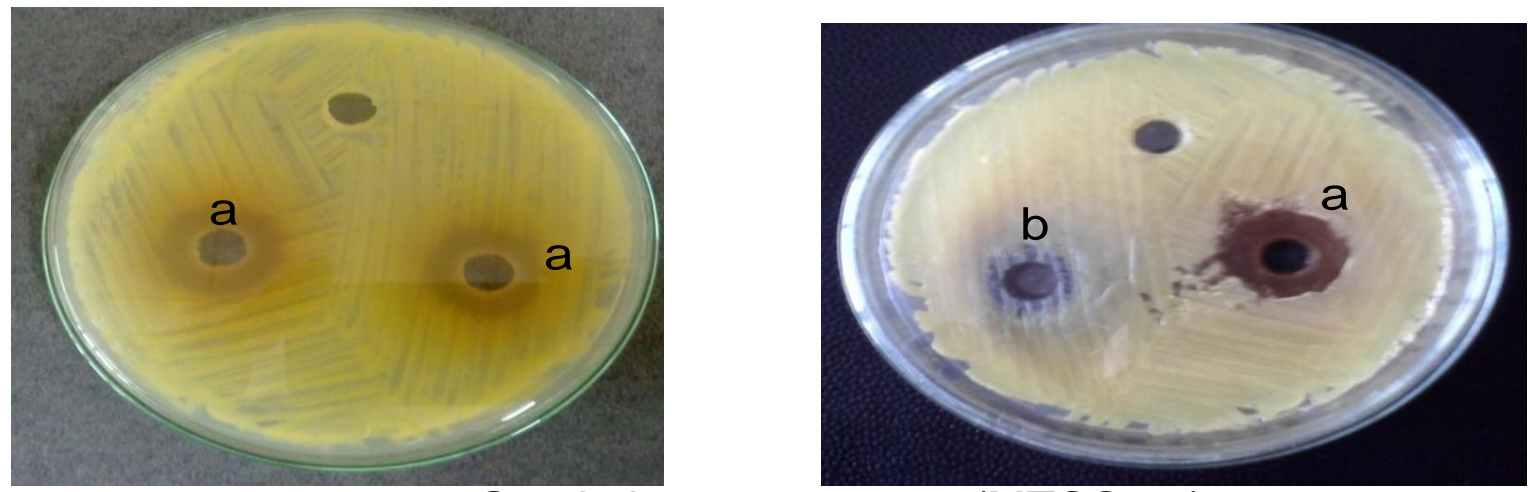

Staphylococcus aureus (MTCC-96)
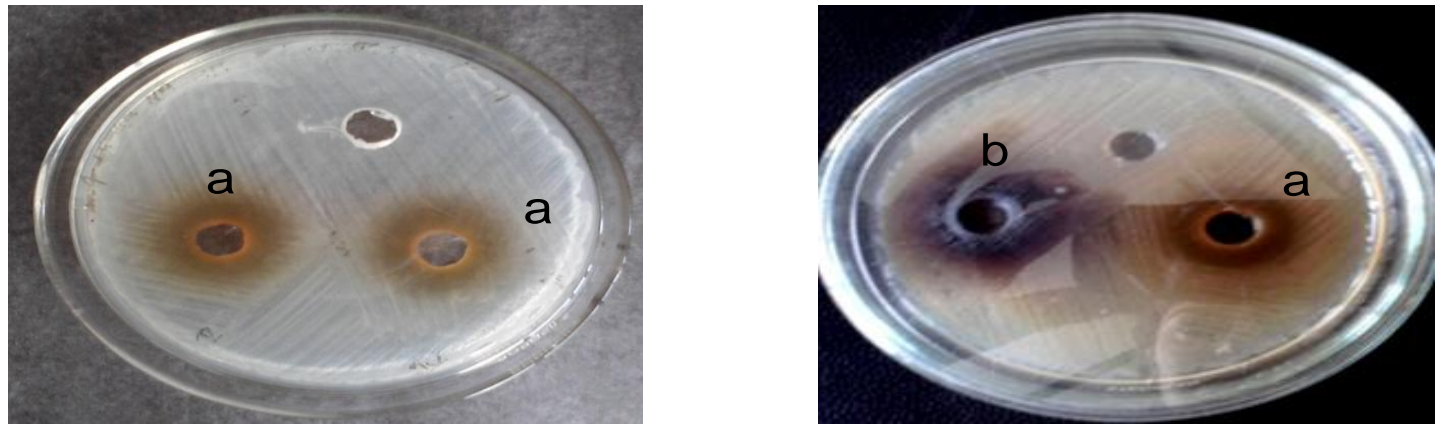

Bacillus cereus (MTCC-1272)

\section{Total catechin content}

Significant mean variations in the levels of TC in tea powders were almost similar to those of in fresh green tea shoots (Table 2). Misra et al., (2008) reported that the fresh tea shoots were extremely rich in phenolic compounds which can constitute up to 300 $\mathrm{mg} / \mathrm{g}$ of dry leaves.

\section{Thin layer chromatography of tea powder}

The chromatogram indicates that the tea powders contain all the five flavanols of interest. Bashir et al., (2014) reported that spot screening of TLC-developed plates indicated that the presence of active biological compounds such as flavonoids, phenols, alkaloids and glycosides.

\section{Metal ions chelation}

The ability of flavanols to bind cations of metals having variable valency will restrict the metal ions from undergoing oxidation which in turn terminate the generation of free electrons/radicals in biological system. Such a reaction may contribute, indirectly, to the antioxidant potential of flavanols.

The metal chelation potential of the tea powders was better than that of citric acid. This could be due to the presence of flavanols in tea powders. Tea catechins have been reported to exhibit significantly $(\mathrm{p}<0.05)$ weaker chelating activity ranging from EGCG (38\%), EC (30\%), ECG (19\%) on $\mathrm{Fe}^{2+}$ ions compared to citric acid $(54 \%)$ or EDTA (100\%) at a concentration of $400 \mathrm{ppm}$ (Tang et al., 2002). 
From significant negative correlation with TC, EGCG, ECG and EGCG+ECG, it is reasonable to infer that the flavanols with gallate moiety (EGCG and ECG) might be responsible for the metal ions chelation activity among tea catechins. Compounds with gallate groups in their molecules, gallate of catechins and their polymers have been reported to exhibit metal ions chelating activity (Miller et al., 1996).

\section{Antibacterial activity}

\section{Sensitivity of selected bacterial pathogens for standard catechins}

The lowest mean MIC among the standard catechins was observed with EGCG against $B$. cereus. The selected bacterial pathogens were resistant against catechin and epicatechin. These results are in agreement with Taguri et al., (2004) who reported higher antibacterial effect of EGCG against all bacterial groups: Staphylococcus aureus (20 strains), Salmonella (26 strains), E. coli (23 strains) and genus Vibrio (27 strains) as compared to EGC suggesting that this could probably be due to the presence of galloyl group in EGCG which increases its antibacterial activity.

Table 5 indicates that the aqueous extracts of samples of fresh green tea shoots harvested during the month of August had lower MIC and hence more potent antibacterial as compared to rest of the months (Plate III). However, Chou et al., (1999) reported that the extract of oolong tea prepared from samples of tea shoots harvested in summer flush seasons exhibited the strongest antimicrobial activity followed by those prepared from samples of spring, winter and fall. The high antibacterial activity of samples August could be due to the presence of high levels of total catechins in the sample as evident from the results given in table 2 . These results corroborate with the earlier studies carried by
Chou and Lin (1987) and Yam et al., (1997) who fractionated tea extract and reported that the fractions rich in EGC, EGCG and ECG exhibit strong antimicrobial activity.

\section{Bioautography}

A comparison with standard catechins TLC chromatogram illustrate that EGCG was present at bottom and hence, EGCG was the active component of tea sample which probably responsible for the antibacterial activity of Kangra tea. These results are in agreement with Freidman et al., (2006) who reported that gallate of catechins i.e. (-)gallocatechin-3-gallate, (-)-epigallocatechin3-gallate, (-)-catechin-3-gallate, (-)epicatechin-3-gallate, theaflavin-3,3'digallate, theaflavin-3'-gallate and theaflavin3-gallate showed antimicrobial activities at nanomolar levels. Bashir et al., (2014) reported that TLC bioautography of methanol, ethanol and DMSO extracts of Camellia varieties indicated the significant inhibition of $S$. aureus, $S$. epidermidis and $S$. marcescens, respectively. Similar results were recorded by spot screening of TLC-developed plates against all clinical bacterial pathogens. The zone of inhibition was recorded in range from $10.00 \pm 0.0 \mathrm{~mm}$ to $28.00 \pm 0.00 \mathrm{~mm}$.

\section{Influence of metal ions on inhibition} properties of tea catechins

It was evident from the plate that addition of ferrous ions restored the growth of organism around the well indicating that the antibacterial activity of tea catechins is probably due to their ability to chelate $\mathrm{Fe}^{2+}$ ions and making them non-available for microbial growth. These observations are in accordance with the earlier studies of West et al., (2001). These results also suggest that the growth inhibition by tea catechins is of bacteriostatic in nature. Earlier studies by Kono et al., (1994) suggested that EGCG has 
a concentration dependant bactericidal activity i.e. at concentration of 1 to 2 times of MIC, the number of bacteria decreased to $1 / 10^{\text {th }}$ of original load, suggesting bacteriostatic activity, but if concentration was increased to 6 fold greater than MIC, then EGCG showed bactericidal activity. However, Freidman et al., (2006) reported bactericidal activities of the aqueous extract of green tea catechins.

The ferrous ions chelation and antibacterial potency of green tea were directly proportional to total catechins contents of tea in general and (-)-epigallocatechin gallate and $(-)$-epicatechin gallate contents in particular. The antibacterial effect of green tea was bacteriostatic instead of bactericidal; however, more work is required to be carried out to establish this property. The flavanols with galloyl moiety exhibit potential biological activity.

\section{References}

Bashir, S., Khan BM, Babar M, Andleeb S, Hafeez M, Ali S and Khan MF. 2014. Assessment of bioautography and spot screening of TLC Of green tea (Camellia) plant extracts as antibacterial and antioxidant agents. Indian Journal of Pharmaceutical Sciences. 364-370

Cabrera, C., Artacho R and Gimenez R. 2006. Beneficial effects of green tea-A review. Journal of the American College of Nutrition 25(2): 79-99.

Chou, C., Lin L and Chung K. 1999. Antimicrobial activity of tea as affected by the degree of fermentation and manufacturing season. International Journal of Food Microbiology 48(6): 125-130.

Chou, C.C., and Lin L. 1987. Antimicrobial activity of tea flush. In: Proceeding of $2^{\text {nd }}$ World Congress of Food Technology, Barcelona, Spain pp 287 -
296.

Duthie, G.G., Duthie SJ and Kyle JAM. 2000. Plant polyphenols in cancer and heart disease: Implications as nutritional antioxidants. Nutrition Research Review 13(1): 79-106.

Freidman, M., 2007. Overview of antibacterial, antitoxin, antiviral, and antifungal activities of tea flavonoids and teas. Molecular Nutrition and Food Research 51(1): 116 - 134.

Friedman, M., Henika PR, Levin CE, Mandrell RE and Kozukue N. 2006. Antimicrobial activities of tea catechins and the aflavins and tea extracts against Bacillus cereus. Journal of Food Protection 69(2): $354-361$.

Gogoi, A.S., and Borua P K. 2017. Profiling of total polyphenols and pigments in tea (camellia Sinensis (L.) O. Kuntze) in various seasons for manufacturing black tea and green tea. International Journal of Food Nutrition and Science. 6, No. 2: 56-67.

Gramza, A., Korczak J and Amarowicz R. 2005. Tea polyphenols - their antioxidant properties and biological activity- a review. Polish Journal of Food and Nutrition Sciences 14(3): 219-235.

Kline, R.M., and Golab T. 1965. A simple technique in developing thin-layer bioautographs. Journal of Chromatography A 18:409-411.

Koehn, F.E., Carter GT. 2005.The evolving role of natural products in drug discovery. Nat Rev Drug Discov; 4:20620.

Kono, K., Tatara I, Takeda S, Arakawa K and Hara Y. 1994. Antibacterial activity of epigallocatechin gallate against methicillin-resistant Staphylococcus aureus. Kansenshogaku Zasshi 68(12):1518-1522.

Marwat, S.K., Khan MA, Ahmad M, Zafar M, Rehman F. 2008.Ethnomedicines for 
treatment of various diseases in D.I. Khan District. Sarhad. J Agric., 24:2.

Miller, N.J., Castelluccio C, Tijburg L and Rice-Evans C. 1996. The antioxidant properties of theaflavins and their gallate esters-radical scavengers or metal chelators. FEBS Letters 392(1): 40-44.

Misra, T.K., Saha A, Nanda A K and Mandal P (2008),"Variation of antioxidant properties and phytochemical constituents of tea cultivated under various agronomic conditions of North Bengal, NBU".Journal of Plant Sciences, Vol. 2, pp. 58-66.

Nakagawa, K., Ninomiya M, Okubo T, Aoi N, Juneja LR, Kim M, Yamanaka K and Miyazawa T. 1999. Tea catechin supplementation increases antioxidant capacity and prevents phospholipid hydroperoxidation in plasma of humans. Journal of Agricultural and Food Chemistry 47(10): 3967-3973.

Nathan, C., Antibiotics at the crossroads. 2004. Nature; 431:899-902.

Sharma, V.K., Bhattacharya A, Kumar A and Sharma HK. 2007. Health Benefits of Tea Consumption. Tropical Journal of Pharmaceutical Research 6 (3): 785792.

Stahl, E., 1969. Thin layer chromatographyA Laboratory Handbook. Springer International Student Edition.

Sun, B., Ricardo-da silva J M and Spranger I. 1998. Critical factors of vanillin assay for catechins and Proanthocyanidins. Journal of Agricultural and Food Chemistry 46(10): 4267-4274.

Taguri, T., Tanaka T and Kouno I. 2004.
Antimicrobial activity of 10 different plant polyphenols against bacteria causing food-borne disease. Biological Pharmaceutical Bulletin 27(12): 19651969.

Tang, S.Z., Kerry JP, Sheehan D and Buckley DJ. 2002. Antioxidative mechanisms of tea catechins in chicken meat systems. Food Chemistry 76(1):45-51.

Toda, M., Okubo S, Hiyoshi R and Shimamura T.1989a. Antibacterial and bactericidal activities of Japanese green tea. Japan Journal of Bacteriology 44(4): 669-672.

Walsh, F.M., Amyes SG. 2004. Microbiology and drug resistance mechanisms of fully resistant pathogens. Curr Opin Microbiol., 7:439-44.

West, P.W.J., Mathew TC, Miller NJ and Electricwala Q. 2001. The effect of green tea on the growth and morphology of mithicillin-resistant and methicillin-susceptible Staphylococcus aureus. Journal of Nutritional and Environmental Medicine 11(4):263-269.

Yam, T.S., Shah S and Hamilton-Miller JM. 1997. Microbiological activity of whole and fractionated crude extracts of tea (Camellia sinensis) and of tea components. FEMS Microbiology Letters 152(1): $169-174$.

Yamamoto, T., Juneja LR, Chu D and Kim M. 1997. Chemistry and application in green tea. Boca Raton, USA: CRC Press.

Yilmaz, Y., 2006. Novel uses of catechins in foods. Trends Food Science and Technology 17(2):64-71.

\section{How to cite this article:}

Arti Ghabru and Sud, R.G. 2017. Assessment of Metal Chelating, Bioautography and Spot Screening by TLC of Green Tea (Camellia sinensis). Int.J.Curr.Microbiol.App.Sci. 6(10): 302313. doi: https://doi.org/10.20546/ijcmas.2017.610.037 